\title{
Kontribusi Pondok Pesantren Haji Ya'qub Lirboyo Kediri dalam Mengembangkan Pendidikan Politik Islam di Indonesia
}

\author{
Ahmad Sodikin \\ Sekolah Tinggi Ilmu Syari'ah Faqih Asy'ari Kediri, Indonesia \\ e-mail; shodzu@gmail.com
}

\begin{abstract}
Speaking of pesantren and Islamic politics, it cannot be separated from Islam and its people, while Muslims have been encouraged by their leaders (although in minority number) that to not mix religion with politic, especially in Indonesia in the 1980s so that there is an impression that Muslims do not need to engage in politic mainly in the pesantren community and that's why Muslims and their leaders become afraid talking about politics. It encourages the writer to find out more about how political education in pesantren which finally the writer do research in the pesantren in particular pesantren of Haji Ya'qub Lirboyo in Kediri.

The type of research used was qualitative descriptive. Because the research aimed to describe the phenomena at the research location. This research succeeded in obtaining findings according to the problem questions which in the outline can be summarized as follows: Islamic political education in pesantren of Haji Ya'qub Lirboyo indirectly existed since the time of its establishment, but limited only to the role model of the kyais. On the other hand, the form of political education such as organizations still exist, for example Jamiyyah, Bahtsul Masa'il Institution, and Madrasah Diniyah. While education that is purely in the form of lesson is understanding Nahdlatul Ulama (NU) and Civics that learned in public school.

Contribution of Haji Ya'qub Islamic boarding school in Islamic political education consisted of two types which is fund and behavior. In the form of fund contribution was donation to the local election committee. Whereas in the form of the behavior, the Haji Ya'qub Islamic boarding school formed organizations such as LBM, Jamiyyah, and Madrasah Diniyah.
\end{abstract}

\section{Keywords: Contribution of Islamic Boarding School, Islamic Political Education}

\section{Pendahuluan}

Era Reformasi saat ini memberikan peluang yang besar kepada segenap elemen bangsa untuk ikut berpartisipasi aktif dalam kancah perpolitikan baik di daerah maupun nasional. Dinamika politik saat ini dimana yang menjadi modal utama dalam berkompetisi adalah popularitas, dengan demikian kecenderungan bahwa orientasi politik yang terbangun di masyarakat tidak jelas. Fenomena yang seperti ini bisa menjadi jawaban atas kekecewaan masyarakat kepada partai politik.

Pondok pesantren sebagai sebuah lembaga pendidikan, juga sering dijadikan sebagai komoditas politik oleh politikus yang berkepentingan sehingga sering dijumpai ketika musim kampanye para kandidat dan tim suksesnya mendatangi pondok pesantren dengan berbagai modus. Namun pada hakikatnya kandidat tersebut sebenarnya meminta restu kepada kiai-kiai sekaligus meminta dukungan spiritual dan dukungan massa.

Untuk mendapatkan dukungan massa yang lebih banyak, pada setiap pemilihan umum (Pemilu) maka suara kiai dan santri selalu diperebutkan bukan saja oleh partai-partai politik berbasis Islam saja melainkan juga partai-partai politik berbasis nasionalis. Dalam upaya meraup simpati dari kalangan Islam yang menjadi pengikut setia kiai, banyak partai politik yang menempatkan kiai dan 
tokoh pesantren pada jajaran pengurus partai dengan harapan dapat menjadi magnet dalam pemilu. Kecenderungan menarik dukungan kiai dan tokohtokoh pesantren tersebut memperlihatkan bahwa nilai politik kiai di hadapan para politisi dalam upaya mereka membangun basis dukungan ataupun sekedar legitimasi bagi kepentingan politiknya masih cukup tinggi.

Masuknya kiai dan santri dalam politik praktis memiliki dampak positif yaitu kiai dan santri dapat mengembangkan praktek politik yang sehat dan mengembangkan politik Islam, namun di lain sisi juga memiliki dampak negatif dimana kiai dan santri yang masuk politik praktis menjadikan kiai dan santri tersebut cacat dimata sebagian masyarakat dan sering terjadi kiai yang berpolitik tersandung kasuskasus hukum misalnya korupsi dan nepotisme.

Apabila melihat prilaku politik santri tidak terlepas dari peran kiai. Kiai di hadapan santrinya merupakan tokoh panutan penebar keilmuan dengan kharismanya hingga tidak berlebihan fatwafatwanya dianggap sakral dan sulit ditolak sebagai bentuk ketaatan yang secara teologis memiliki dasarnya. Ketaatan santri pada kiai dalam hal berpolitik masih sulit untuk dilepaskan sehingga kecenderungan apa yang diputuskan kiai tentang pandangan politik (pilihan politik) sesuatu yang tidak dapat dibantah sebab apabila dibantah ini menunjukkan pembangkangannya dan lebih ekstrim lagi ini dianggap sebagai perbuatan dosa sebab melawan keputusan kiai.

Cara pandang yang seperti ini perlu diluruskan, ini merupakan pembodohan sebab "perbedaan itu adalah rahmat", berpolitik adalah urusan dunia, berpolitik merupakan sarana untuk menyampaikan aspirasi, Apabila seseorang yang akan diberikan amanah untuk menyampaikan aspirasi tidak dapat dipercaya maka tidak mungkin seseorang dipaksa untuk mengikuti seseorang yang tidak dapat dipercaya. Seorang kiai tidak dapat dijamin pilihannya terhadap salah satu partai atau kepada salah satu kandidat itu berdasarkan AlQur'an dan Al- Hadis, Memungkinkan ada kepentingan lain dibalik partai pilihan kiai, maka dari itu sangat naif jika pilihan santri berbeda dengan kiai dianggap melawan fatwa.

Pembelajaran politik merupakan suatu keniscayaan kepada masyarakat, tentunya pembelajaran politik yang baik, beretika, dan menjunjung tinggi nilai- nilai pluralitas. Sehingga tidak ada pemaksaan dalam berpolitik, baik pemaksaan secara langsung maupun tidak langsung. Pemaksaan tidak langsung misalnya money politic money politic, riswah, dan gratifikasi.

Demokrasi sebagai sebuah sistem yang dianut oleh Negara ini dalam hal perpolitikan nasional memungkinkan memberikan akses kepada seluruh elemen masyarakat untuk ikut berpartisifasi aktif dalam politik praktis. Santri sebagai salah satu elemen penting dalam perpolitikan nasional juga hendaknya memiliki kepedulian tinggi untuk urusan politik dan tetap netral dalam menjalankan hak politiknya tanpa tendensi dari pihak manapun juga. Oleh sebab itu, menurut hemat penulis pendidikan politik sangat dibutuhkan untuk menumbuhkan kesadaran berpolitik, pendewasaan dalam berpolitik, dan yang terpenting untuk menghindari adanya tendensi dalam berpolitik

Berbicara soal pesantren dan politik Islam, maka tidak lepas dari Islam dan umatnya, sementara umat Islam pernah ada semacam anjuran dari para tokohnya (meski jumlahnya minoritas) agar tidak mencampurkan agama dengan politik terutama di Indonesia pada tahun 1980-an sehingga ada kesan bahwa umat Islam tidak perlu berpolitik apalagi dalam masyarakat pesantren dan karena itulah orang Islam dan para tokohnya menjadi phobi berbicara soal politik. Dari sini muncul pertanyaan, benarkah umat Islam berhenti berpolitik terutama dikalangan pesantren? Benarkah pesantren selama ini tidak kenal politik atau tidak pernah berpolitik?

Hal tersebut mendorong penulis untuk mengetahui lebih lanjut bagaimana pendidikan politik di pesantren yang akhirnya penulis melakukan penelitian di pesantren khususnya pesantren Haji Ya'qub Lirboyo Kediri. Pesantren Haji Ya'qub dipilih menjadi tempat penelitian karena pesantren ini merupakan pesantren unit Lirboyo yang telah ada semenjak Indonesia belum merdeka tepatnya sekitar pada tahun 1910. Seperti yang telah dijabarkan sebelumnya bahwa ketika masa penjajahan Belanda dan pada masa Orde Baru, pondok pesantren dilarang untuk berhubungan dengan politik maka penulis ingin mengetahui apakah pesantren Haji Ya'qub Lirboyo Kediri juga termasuk pesantren yang mengisolasi diri dari politik 
terutama dalam hal pewarisan nilai-nilai politik pada para santrinya ataukah justru berperan aktif dalam perpolitik semenjak berdirinya pondok pesantren ini.

\section{Landasan Teori}

Pendidikan politik sering disebut istilah political forming atau politische bildung. Disebut forming karena di dalamnya terkandung intensitas untuk membentuk insan politik yang menyadari status, kedudukan politiknya di tengah masyarakat. Disebut bildung (pendidikan diri sendiri) karena istilah ini menyangkut aktivitas membentuk diri sendiri dengan kesadaran penuh tanggung jawab untuk menjadi insan politik. Pendidikan politik pada hakikatnya adalah sebagai bagian dari pendidikan orang dewasa, karena hal ini menyangkut relasi antar individu, antar individu dengan masyarakat di tengah medan sosial, dalam situasi-situasi konflik yang ditimbulkan oleh bermacam-macam perbedaan kemajemukan masyarakat.

Pendidikan politik bagi warga negara adalah penyadaran warga negara untuk sampai pada pemahaman politik atau aspek-aspek politik dari setiap permasalahan sehingga dapat mempengaruhi dan ikut mengambil keputusan di tengah medan politik dan pertarungan konflik-konflik. Pendidikan politik ini diselenggarakan sebagai upaya edukatif yang sistematis dan intensif untuk memantapkan kesadaran bernegara. ${ }^{1}$

Setiap gerakan yang memasuki wilayah politik. Apakah ia wujud dalam bentuk partai politik, ormas, jama'ah, atau Lembaga Swadaya Masyarakat (LSM), tidak akan pernah melupakan pendidikan politik. Hal tersebut disebabkan kedudukannya dalam jagat politik sangat penting dan tidak dapat dipisahkan, yaitu sebagai sarana pembentukan kader yang berperan aktif dalam bidang politik dan pembentukan kesadaran politik bagi warga umumnya, sehingga mereka mampu mandiri secara politik, tidak mudah dipatron oleh kekuasaan yang ada, selanjutnya mampu berpartisipasi dalam segala kegiatan politik.

Secara umum, pendidikan politik dipandang sebagai aktivitas pendidikan yang terlembagakan,

\footnotetext{
${ }^{1}$ M. Nur Khoiron, dkk, Pendidikan Politik Bagi Warga Negara: Tawaran Konseptual dan Kerangka Kerja (Yogyakarta: LKIS, 1999), h. 4.

2 Abu Ridha, Pengantar Tarbiyah Siyasiyah (Bandung: PT Syaamil Cipta Mesia, 2002), h.39 - 40.
}

yang secara teratur, sistematik, dan intensional melakukan berbagai upaya mendorong warga di sebuah negara atau pendukung di sebuah pergerakan untuk berpartisipasi lebih aktif dalam membangun institusi kemasyarakatan dan politik. Dalam kaitan ini, pendidikan politik tidak dapat lepas dari proses pembinaan masyarakat, agar mereka menyadari hak dan kewajiban politiknya terhadap tanah air atau terhadap gerakannya. ${ }^{2}$

Pesantren merupakan suatu komunitas tersendiri, dimana kyai, ustadz, santri dan pengurus pesantren hidup bersama dalam satu kampus, berlandaskan nilai-nilai agama Islam lengkap dengan norma-norma dan kebiasaan-kebiasaan tersendiri, yang secara eksklusif berbeda dengan masyarakat umum yang mengitarinya.

Mungkin kebanyakan masyarakat menganggap bahwa pesantren merupakan lembaga keagamaan yang bersifat tradisional dan kolot. Seperti yang di ungkapkan oleh Clifford Geertz yang menilai bahwa kyai dan pesantrennya pada tingkat tertentu masih merupakan inti struktur sosial Islam pedesaan dan merupakan puncak kultur kolot. Sedangkan Fuad Ansyari sangat menyesali eksistensi pesantren salafiyyah yang diyakini membahayakan generasi muda bangsa, atau dengan kata lain bahwa pesantren merupakan kelompok orang-orang Islam tradisional yang telah mengalami stagnasi atau ke'mandeg' $a n .{ }^{3}$

Secara sosiologis peran ulama di tengah-tengah masyarakat khususnya pada komunitas santri, menjadi posisi yang sangat distimewakan. Mereka dihormati dan nasehat-nasehatnya dipatuhi. Status sosial ekonomi mereka beragam, meski pada umumnya berasal dari kelompok bangsawan kaya yang memiliki hamparan tanah yang luas. Akumulasi dari status sosial ditunjang kekayaan dan ilmu pengetahuan agama yang luas menjadikan ulama sebagai pemimpin kharismatik yang disegani.

Kekuatan lain yang melekat pada diri figur ulama, terletak pada kehalusan dan kemampuan menafsirkan paham yang dianut yang kemudian membuat mereka benar-benar sanggup melakukan peran yang oleh Geertz disebut sebagai cultural broker, yaitu menjembatani transformasi nilai-nilai

\footnotetext{
3 Haedari Amin, Khazanah Intelektual Pesantren (Jakarta: Maloho Jaya Abadi, 2009), h. 349-35
} 
kultural berkembang di masyarakat. Dari kelebihan ulama semacam itulah yang membuat ulama terlibat dalam kepemimpinan masyarakat dan terjun dalam dunia politik... ${ }^{4}$

\section{Metode Penelitian}

Terkait dengan jenis dan pendekatan penelitian yang ditentukan, Penelitian ini menggunakan pendekatan kualitatif deskriptif, yaitu "penelitian yang berusaha mendeskripsikan suatu gejala, peristiwa, kejadian yang terjadi pada saat sekarang", 5 sehingga penelitian ini mempunyai kekhasan yang terletak pada tujuannya, yakni mendeskripsikan tentang segala sesuatu yang berkaitan dengan seluruh kegiatan.

Pemilihan pendekatan kualitatif deskriptif ini karena pada penelitian ini berusaha meneliti status kelompok manusia, suatu obyek, suatu sistem pemikiran, atau suatu peristiwa pada masa sekarang dengan tujuan membuat deskripsi, gambaran atau lukisan sistematis, faktual dan akurat mengenai fakta-fakta, sifat-sifat, serta hubungan antar fenomena yang diselidiki. Pada umumnya penelitian kualitatif deskriptif merupakan penelitian nonhipotesis/non-statistik, sehingga dalam langkah penelitiannya tidak perlu merumuskan hipotesis.

Penelitian ini mempunyai ciri khas yang terletak pada tujuannya, yakni mendeskripsikan tentang segala sesuatu yang berkaitan dengan seluruh kegiatan objek penelitian. Adapun yang dimaksud kegiatan di sini adalah kontribusi pondok pesantren Haji Ya'qub Lirboyo Kediri dalam mengembangkan pendidikan politik Islam di Indonesia.

Adapun proses pelaksanaan penelitian kualitatif deskriptif adalah sebagai berikut:

a. Mengumpulkan informasi aktual secara rinci yang melukiskan gejala yang ada.

b. Mengidentifikasi masalah atau memeriksa kondisi dan praktek- praktek yang ada.

c. Membuat perbandingan atau evaluasi.

d. Menentukan apa yang dilakukan orang lain dalam menghadapi masalah yang sama dan belajar dari pengalaman mereka untuk menetapkan rencana dan keputusan pada waktu yang akan datang.

\footnotetext{
${ }^{4}$ Nurul Azizah, Artikulasi Politik Santri dari Kyai Menjadi Bupati (Yogyakarta: Pustaka Pelajar, 2013), h. 61
}

\section{Temuan Penelitian dan Pembahasan \\ Pendidikan politik Islam di pondok pesantren Haji Ya'qub Lirboyo Kediri}

Pondok pesatren Haji Ya'qub merupakan pondok unit dari pondok pesantren Lirboyo induk, maka berdirinya juga setelah pondok induk Lirboyo. Berdasarkan hasil penelitian di atas bahwa pendidikan politik di pesantren Haji Ya'qub sudah ada sejak dulu, dari mulai kepemimpinan mbah Ya'qub bin sholeh, akan tetapi hanya sebatas suri tauladan dari para masyayih. Dari sini dapat peneliti pahami dengan adanya suri tauladan yang baik dari para kyai, sesepuh, yang masih ada hubungannya dengan politik akan dapat dilakukan pula oleh santri. Pendidikan seperti ini memang dinilai lebih efektif karena tidak terlalu memaksa.

Pendidikan politik yang hanya sebatas suri tauladan jika dipandang berdasarkan pendapat Abu Ridha yang mengatakan pendidikan politik dipandang sebagai aktivitas pendidikan yang terlembagakan, yang secara teratur, sistematik, dan intensional melakukan berbagai upaya mendorong warga di suatu Negara atau pendukung di suatu pergerakan untuk berpartisipasi lebih aktif dalam membangun institusi kemasyarakatan dan politik, dari sini dapat disimpulkan bahwa pendidikan politik di awal berdirinya pondok pesantren Haji Ya'qub belum maksimal atau bahkan belum ada.

Semakin berjalannya waktu, berkembanglah pendidikan di pondok pesantren Haji Ya'qub, dengan berdirinya lembaga-lembaga yang berada di dalamnya seperti Madrasah Diniyah, Lembaga Bahtsul Masa'il, Jamiyyah. Hal ini secara tidak langsung mendidik santri untuk belajar berpolitik secara langsung masuk pada organisasi, hampir semua alumni yang sekarang terjun di dunia politik pernah menjabat sebagai ketua jamiyyah dan LBM. Disisi lain Madrasah Diniyah Haji Ya'qub yang merupakan lembaga dalam naungan pondok juga memberikan materi khusus tentang politik, meskipun pelajaran lain juga mengandung unsur politik, Seperti Ke NU an, Fiqih siasah. Pendidikan politik yang berangsur-angsur seperti ini bertujuan untuk menyiapkan santri yang memiliki kepribadian mulia, berjuang di dunia politik dengan cara yang halal,

\footnotetext{
5 Nana Sujana dan Ibrahim, Penelitian dan Penelitian pendidikan (Bandung: Sinar Baru, 1984), h. 64.
} 
seperti yang disampaikan oleh pemikir besar muslim, bahwa politik oleh para pemikir besar muslim diharapkan hanya menjadi media (a means) untuk mencapai tujuan yang jauh lebih penting, yaitu tegaknya kalimat Allah di bumi ini.

\section{Bentuk/implementasi pendidikan politik santri di luar pesantren}

Pendidikan Politik bagi santri pondok pesantren Haji Ya'qub tidak hanya didapat dari dalam pondok, akan tetapi juga dari luar pondok sebagaimana yang telah dijelaskan dari hasil penelitian/temuan penelitian bahwa, dengan diperbolehkannya santri untuk merangkap sekolah umum di luar pesantren ini diharapkan agar santri nantinya pandai dalam bidang agama termasuk ilmu Fiqih, ilmu Nahwu dan lain-lain, dan juga tidak terlewatkan ilmu pendidikan umum seperti kewarganegaraan, matematika, biologi, dan lain sebagainya.

Berdasarkan keterangan di atas menunjukkan bahwa pondok pesantren Haji Ya'qub merupakan pondok pesantren yang mengolaborasikan antara pendidikan agama dengan pendidikan umum dan tergolong pondok pesantren tipe $\mathrm{C}$ yaitu pondok pesantren campuran. Sebagaimana yang terdapat ditentukan Kementerian Agama RI.

Adapun pendidikan politik yang dapat mereka peroleh dari sekolah umum misalnya pembelajaran PPKn, sosiologi selain itu ada beberapa santri yang aktif di organisasi sekolah seperti IPNU, OSIS, hal ini sudah semestinya akan lebih bisa menyadarkan para santri untuk menjadi orang yang sadar akan pentingnya politik, akan lebih bisa mengatur diri, dan mudah menjadi manusia dewasa.

Bagi mereka para santri yang merangkap pendidikan umum di luar pondok tentu akan berbeda dengan mereka yang hanya belajar di pondok. Semua ini tidak lain karena pengaruh pendidikan yang berbeda. Pendidikan santri yang khusus di pondok pesantren cenderung mencetak santri yang salaf dan pendidikan politiknya juga kurang.

\section{Bentuk pendidikan politik di dalam pondok pesantren Haji Ya'qub}

Pendidikan politik yang terjadi di dalam pondok pesantren Haji Ya'qub terlihat dari hasil penelitian, dapat disimpulkan terdapat tiga bentuk pendidikan politik yaitu formal, nonformal dan politik praktis. Pendidikan formal dalam hal ini dapat diartikan dengan pendidikan yang berjenjang dari mulai kelas satu ibtidaiyah sampai dengan tiga aliyah.

Untuk mencetak generasi muslim yang tangguh, cerdas, berakhlak mulia, bijak dan bertanggung jawab tidaklah mudah, maka dari itu didirikanlah sebuah lembaga Madrasah Diniyah yang berada di pondok pesantren Haji Ya'qub, dengan jenjang pendidikan yang cukup lama yaitu 12 tahun. Penyampaian pendidikan politik dengan bentuk sebuah lembaga seperti di atas seiring dengan Rusadi Kartaprawira: "bahwa pendidikan politik dapat dilakukan melalui lembaga atau asosiasi dalam masyarakat seperti masjid atau gereja tempat menyampaikan khotbah, dan juga lembaga pendidikan formal ataupun informal"

Pendidikan politik di pondok pesantren Haji Ya'qub dalam bentuk nonformal sangat mempengaruhi terhadap kepribadian politik santri, Berdasarkan hasil penelitian baik wawancara, observasi, maupun dokumentasi membuktikan bahwa salah satu kegiatan nonformal seperti jamiyyah yang dilakukan satu minggu sekali, mampu untuk menjadikan seorang santri mempunyai mental, percaya diri dan para pengurus jamiyyah juga akan lebih mampu dalam berorganisasi.

Jamiyyah yang biasa dilaksanakan setiap malam jum'at bentuk kegiatannya antara lain belajar pidato, tahlil, belajar menjadi MC, Qiro'at, puisi, dan seminar satu bulan sekali. Materi pendidikan politik yang cenderung lebih banyak praktek dari pada materi hal ini akan lebih mudah diterima oleh para santri. Kegiatan seperti ini juga sesuai dengan apa yang telah diunggapkan oleh robert Brownhiil "salah satu kurikulum pendidikan politik adalah Keahlian berkomunikasi: mempresentasikan argumen secara lisan dan tulisan, berpidato, seni dalam berdebat, dan teknik persuasif.

\section{Kontribusi pondok pesantren Haji Ya'qub dalam pengembangan pendidikan politik Islam}

Secara umum kontribusi pondok pesantren 
Haji Ya'qub dalam pendidikan politik berdasarkan hasil penelitian bisa terlihat dari segi material dan perilaku. Adapun kontribusi material yang telah diberikan oleh pihak pondok di antaranya sumbangan dana yang diberikan kepada panitia pemilu tahun 2015 yang bertempat di ndalem agus Yusuf Khozin, sumbangan dana untuk membangun Madrasah Diniyah Haji Ya'qub guna terselenggaranya proses belajar mengajar.

Sedangkan dari segi perilaku pondok pesantren Haji Ya'qub lebih banyak menekankan kepada para santri untuk aktif dalam organisasi yang ada dalam pondok pesantren seperti Jamiyyah, LBM, MGS, dengan seperti ini seorang santri akan terbiasa dalam berorganisasi, mengurus masyarakat, berinteraksi dengan masyarakat.

Pondok pesantren Haji Ya'qub juga mendirikan madrasah diniyah selain sebagai lembaga yang mendidik santri dalam keilmuan agama, kemasyarakatan, dan politik, juga mendidik para pengurusnya agar lebih pandai dalam keadministrasian, dan sistem keorganisasian yang ada di madrasah diniyah itu sendiri. Semua pengurus dituntut untuk menjalankan madrasah dan pondok dengan maksimal, tentu akan berbeda antara santri yang belum pernah mengabdi di pondok dan juga madrasah dengan santri yang hanya sebatas mengaji kemudian boyong atau keluar, terutama dari segi pengalamannya berorganisasi.

Menurut peneliti dari penjelasan di atas, menunjukkan bahwa pondok pesantren tidaklah termasuk lembaga yang kolot, tradisional akan tetapi pondok pesantren sekarang menjadi sebuah lembaga pendidikan yang serba ada, dari mulai pendidikan akhlak, pendidikan agama, pendidikan ekonomi, dan organisasi. Hal yang sama disampaikan oleh Amin Haedari dalam bukunya yang disampaikan oleh Fuad Ansyari dia sangat menyesali eksistensi pesantren salafiyyah yang diyakini membahayakan generasi muda bangsa, atau dengan kata lain bahwa pesantren merupakan kelompok orang-orang Islam tradisional yang telah mengalami stagnasi atau ke'mandeg'an.

\section{Kesimpulan}

Berdasarkan hasil penelitian dan analisisnya maka penlitian ini dapat disimpulkan bahwa pendidikan politik Islam di pondok pesantren Haji Ya'qub Lirboyo Kediri secara tidak langsung telah ada sejak masa berdirinya, akan tetapi hanya sebatas suri tauladan dari para kyai /sesepuh.. Secara umum materi kusus pendidikan politik tidak ada, akan tetapi dari sisi lain bentuk pendidikan politik seperti organisasi tetap ada, seperti Jamiyyah, Lembaga Bahtsul Masa'il, Madrasah Diniyah. Adapun yang dari segi materi juga terlaksana melalui madrasah diniyah seperti ke-NU-an dan lain-lain.

Selain itu, kontribusi pondok pesamtrem Haji Ya'qub Lirboyo Kediri dalam pendidikan politik Islam terdiri dari dua macam yaitu material dan prilaku. Bentuk kontribusi material berupa sumbangan kepada panitia pemilu setempat, sumbangan dana untuk membangun madrasah diniyah sebagai lembaga yang menangani pendidikan politik. Sedangkan yang berupa perilaku pondok pesantren Haji Ya'qub membentuk organisasi-organisasi seperti LBM, Jamiyyah, dan juga madrasah diniyah semuanya itu tidak lain hanya untuk mendidik para santri dalam dunia politik maupun keilmuan agama. 


\section{Daftar Pustaka}

Amin, Haedari. Khazanah Intelektual Pesantren. Jakarta: Maloho Jaya Abadi. 2009.

Azizah, Nurul. Artikulasi Politik Santri dari Kyai Menjadi Bupati. Yogyakarta: Pustaka Pelajar. 2013.
Khoiron, M. Nur dkk. Pendidikan Politik Bagi Warga Negara: Tawaran Konseptual dan Kerangka Kerja. Yogyakarta: LKIS. 1999.

Ridha, Abu. Pengantar Tarbiyah Siyasiyah. Bandung: PT Syaamil Cipta Mesia. 2002.

Sujana, Nana dan Ibrahim. Penelitian dan Penelitian pendidikan. Bandung: Sinar Baru. 1984.

Copyright (C) 2018 Journal Dirasah: Vol. 1, No. 2, August 2018, p-ISSN: 2615-0212, e-ISSN; 26212838

Copyright rests with the authors

Copyright of Jurnal Dirasah is the property of Jurnal Dirasah and its content may not be copied or emailed to multiple sites or posted to a listserv without the copyright holder's express written permission. However, users may print, download, or email articles for individual use. https://ejournal.stisfa-kediri.ac.id/index.php/dirasah 